UCRL- 88575, Rev 1

PREPRINT

\title{
Chemical Analyses of Geothermal Waters and \\ Strategic Petroleum Reserve Brines \\ for Strategic and Precious Metals
}

Jackson E. Harrar and Ellen Raber

This paper was prepared for submittal

to

Journal of Geochemical Exploration

June, 1983

This is a preprint of a paper intended for publication in a journal or proceedings. Since changes may be made before publication, this preprint is made arailable with the understanding that it will not be cited or reproduced without the permission of the author. 


\section{DISCLAIMER}

This report was prepared as an account of work sponsored by an agency of the United States Government. Neither the United States Government nor any agency Thereof, nor any of their employees, makes any warranty, express or implied, or assumes any legal liability or responsibility for the accuracy, completeness, or usefulness of any information, apparatus, product, or process disclosed, or represents that its use would not infringe privately owned rights. Reference herein to any specific commercial product, process, or service by trade name, trademark, manufacturer, or otherwise does not necessarily constitute or imply its endorsement, recommendation, or favoring by the United States Government or any agency thereof. The views and opinions of authors expressed herein do not necessarily state or reflect those of the United States Government or any agency thereof. 


\section{DISCLAIMER}

Portions of this document may be illegible in electronic image products. Images are produced from the best available original document. 
CHEMICAL ANALYSES OF GEOTHERMAL WATERS AND STRATEGIC PETROLEUM RESERVE BRINES FOR STRATEGIC AND PRECIOUS METALS

\author{
J. E. Harrar and E. Raber
}

Lawrence Livermore National Laboratory

University of California, Livermore, California 94550

ABSTRACT

Waters from seven hydrothermal-geothermal, one geopressured-geothermal, and six Strategic Petroleum Reserve wells have been surveyed for twelve metals of special strategic and economic importance using trace chemical analysis techniques. The elements sought were $\mathrm{Cr}, \mathrm{Co}, \mathrm{Mn}, \mathrm{Ta}, \mathrm{Sn}, \mathrm{V}, \mathrm{Nb}$, $\mathrm{Li}, \mathrm{Sr}, \mathrm{Pt}, \mathrm{Au}$, and $\mathrm{Ag}$. Platinum was found at a concentration of $250 \mathrm{ppb}$ in a brine from the Salton Sea geothermal area. Brine from this region, as has been known from previous studies, is also rich in Li, Sr, and $\mathrm{Mn}$. Higher concentrations ( $9900 \mathrm{ppm})$ of $\mathrm{Sr}$ are found in the high-salinity geopressured brines. None of the fluids contained interesting concentrations of the other metals. Good recovery of precious metals at sub-ppm concentrations from synthetic high salinity brines was achieved using Amborane reductive resin, but similar recovery in the laboratory using real brines could not be demonstrated. Several analytical techniques were compared in sensitivity for the determination of the precious metals; neutron activation analysis with carrier separation is the best for gold and platinum in geothermal brines. 


\section{INTRODUCTION}

The significance and implications of U.S. dependence on what are considered strategic materials have received increasing attention recently. These are materials that have widespread essential use in military and industrial hardware, are not found or produced in the U.S. in sufficient quantity to meet the demand, and are likely to be subject to interruptions in supply because of the actions of cartels or political activities. A number of the industrially important metals can be classified as strategic materials, but those of greatest concern are chromium, cobalt, manganese, tantalum, tin, and the platinum metals, particularly platinum itself. A comprehensive, authoritative review of the institutional and technical issues involved in defining the U.S. position with respect to these strategic materials has been published by Maimoni and Borg $(1981,1982)$.

Possible domestic sources of strategic metals that have not been explored in detail previously are (1) the waters from geothermal wells that are now under active development, (2) the brines produced during the leaching of salt domes on the U.S. Gulf coast for strategic oil storage, and (3) waters from geopressured-geothermal wells under investigation for methane recovery. Even though the concentrations of strategic metals in these waters may be low, the very large volumes of fluid that are processed and now discarded make them attractive resources, especially if economical hydrometallurgical extraction techniques can also be devised.

Several hydrothermal geothermal fluids, particularly the high-temperature, high-salinity brines, are known to be rich in minerals (Cosner and Apps, 1978; Shannon, 1978), and interest in geothermal mineral recovery along with power generation has been slowly growing 
(Maimoni, 1982; Raber et al, 1981; Crane, 1982; Wei, 1982; Schultze and Bauer, 1982). Although several of the geothermal brines have been analyzed for a few of the strategic metals, no concerted effort has been directed toward a more accurate characterization of these fluids in the context of a strategic materials program. Some of the strategic metals are not normally determined in a routine chemical analysis, and the concentration levels of interest for metals such as platinum require very specialized techniques for accurate measurement.

Geopressured-geothermal brines offer another class of potential fluids for mineral recovery. These fluids are being tested at a number of deep wells in Texas and Louisiana, are of interest primarily for their methane content, and their utilization is in an earlier stage of development than the hydrothermal-geothermal resources (Westhusing, 1981). Like some of the mineral-rich hydrothermal fluids, the geopressured brines are also highly saline.

Salt dome leaching is presently being utilized to create large underground caverns for storage applications. The largest scale of such an activity is the U.S. Strategic Petroleum Reserve (SPR) (Davis, 1981), where large quantities of brine are presently discharged into the Gulf of Mexico. A previous preliminary analysis of one of these brines (Raber, et al, 1981) indicated a promising economic concentration of platinum.

In the work described here, a number of hydrothermal-geothermal, one geopressured-geothermal, and several SPR fluids were sampled and analyzed for a suite of strategic metals. The fluid samples were carefully obtained under conditions that assured representative samples. Extra precautions were taken to avoid contamination and to insure stability of the samples prior to analysis, and where possible, each metal was determined by two or more independent analytical facilities or 
techniques. The principal techniques of analysis were fire assay and neutron activation analysis for the precious metals, and direct spectroscopic analysis of the fluids for the other elements. We also conducted a preliminary study of the use of a reductive resin for the extraction of metals from the high-salinity brines.

\section{FLUIDS SAMPLEU AND METALS DETERMINED}

Table 1 lists the various sources of the samples of water examined in this study. The principal characteristics of these well fluids have been documented elsewhere in studies dealing with each site. It is of interest in the present work to note that they ranged from the SPR brines, which were saturated in salt ( 226\% Total Dissolved Solids), to those of very low dissolved solids (e.g., Wen No. 1, <0.1x). The Sweet Lake geopressured brine and the Elmore No. 2 geothermal brines also are high-salinity fluids $(15-22 \%)$. The downhole temperatures of the fluids range from the nearly ambient temperature of the SPR brines, through the relatively low temperature geothermal waters such as Wen No. $1\left(117^{\circ} \mathrm{C}\right)$, to the extremely hot $\left(358^{\circ} \mathrm{C}\right)$ Hawaijan well HGP-A.

Because of our multielement analytical capabilities and those of our subcontractors, a number of elements were determined in each water sample. However, the principal elements of interest were the following strategic metals: Chromium $\left(\mathrm{C}_{r}\right)$, cobalt $\left(\mathrm{C}_{0}\right)$, manganese $\left(\mathrm{Mn}_{n}\right)$, tantalum $(T a)$, tin $\left(S_{n}\right)$, and platinum (Pt). Among this group, tin is the least critical. Because they are of special interest in geothermal mineral recovery, gold $(A u)$, silver $(A g)$, and lithium $(L i)$ were also determined. Vanadium $(V)$ and niobium ( $N \mathrm{~b}$ ) were added to our list on the basis of criticality and, respectively, low stockpile level and high import 
reliance (Maimoni and Borg, 1981). Strontium (Sr) also has a high import reliance, but from a relatively stable source, Mexico (Maimoni and Borg, 1981); this metal was included primarily because its concentration is generally relatively high and easy to measure in natural brines.

\section{EXPERIMENTAL}

\section{Sampling Procedures}

With the exception of one sample (Sulphur Mines 62), all of the waters analyzed in this study were obtained from facilities in which the fluid had flowed for a significant length of time prior to sampling. In the case of the new wells (e.g., Elmore No. 2 and Coso No. 7587) samples were obtained late in the flow test. In the case of the SPR Sulphur Mines No. 62, stagnant brine in the well casing was sampled. Wellhead fluid cooled by flow through a cooling coil constituted the samples at Wen No. 1 and Raft River. At Elmore No. 2, East Mesa 6-2, Coso No. 7587, and HGP-A, samples were obtained from the quench-cooled liquid outputs of the wellhead separators or silencers.

Two types of primary sample containers were used, selected to minimize contamination and loss of trace elements by adsorption (Robertson, 1968, 1972). One was a 4-liter, linear (high-density) polyethylene bottle with polypropylene cap (Nalgene Cat. No. 2125-4000) and the other was a 2-liter FEP-Teflon bottle with ETFE-Teflon cap (Na)gene Cat. No. 1600-0064). These containers were first cleaned by a procedure based on the recommendations of Laxen and Harrison (1981), which consisted of rinsing with water, soaking with $10 \% \mathrm{HNO}_{3}$ for $>24 \mathrm{~h}$, rinsing, then soaking with $1 \% \mathrm{HCl}$ for $>24 \mathrm{~h}$, rinsing, and finally soaking with water for $>24 h$. 
Except for some of the samples that were mixed with reductive resins, all of the samples were stabilized immediately after sampling by acidification with hydrochloric acid to a concentration of $1 \%$. The $\mathrm{HCl}$ was J. T. Baker high-purity Ultrex grade. In addition, the high salinity and high-silica brines were diluted $u 1: 1$ with high purity distilled water to minimize precipitation of their major and trace components.

All of the waters except those from the SPR sites were perfectly clear in appearance at the time of sampling; however, we did not filter any of the samples prior to stabilization. Our basic philosophy here was to seek particular elements without regard to their chemical state. If promising levels were found, then filtered samples could also be tested. In addition, promptness of stabilization of the sample was important; it is possible that some species may precipitate or be adsorbed on precipitates during filtrations and be lost.

\section{Evaporation of Brines}

To prepare the samples for fire assay, portions of the high-salinity brines were evaporated to the dry salts using the apparatus shown in Figure 1. The containers were Fluoroware, Inc. Type E13, 2500-m1 PFA-Tefion conical tanks, which were used as both the top and bottom of the evaporation chamber. The hot plate control was set to give a surface temperature of $150^{\circ} \mathrm{C}$. Except for an ocean water blank, 1-2 kg of brine was evaporated to yiela $250-400 \mathrm{~g}$ of salt. After the evaporation, the salts were broken up and removed to sample bottles using a Kel-F chisel and Tefion forceps. The salts were not further crushed or homogenized. All of this apparatus was cleaned with $10 \% \mathrm{HNO}_{3}$. 
Reaction of Waters with Amborane Resin

Each of the waters except the Sweet Lake geopressured brine was reacted with Rohm and Haas Company Amborane- 355 reductive resin (Rohm and Haas, 1980; Manziek, 1982). A weighed portion of $232 \mathrm{~g}$ of Amborane was added to one of the 4-liter bottles of water immediately after sampling at the wellhead and mixed thoroughly. The mixture was agitated naturally in transit to the Lawrence Livermore National Laboratory; subsequently, the bottles were placed on rollers and subjected to additional mixing for 4 hours. At least one week elapsed between the time of fluid sampling and final filtration of the resin.

The Amborane resin was removed from the waters by vacuum filtration through a $110-\mathrm{mm}$, coarse Tefion filter in a polypropylene Buchner funnel. The resin was rinsed with water several times and dried under vacuum in the funnel. The final weights of each resin sample prepared in this manner ranged from $34-72 \mathrm{~g}$. Prior to use, the Teflon filters were leached with $10 \% \mathrm{HCl}$ and the funnels cleaned with $10 \% \mathrm{HNO}_{3}$.

\section{Standard Solution Preparation}

Standard solutions of platinum, gold, and silver were prepared from, respectively, Spex No. AQPT-3-100 spectrographic standard solution, Marz-grade $\mathrm{Au}$ wire, and reagent-grade $\mathrm{AgNO}_{3}$ salt. Aliquots of these solutions were added to various synthetic brines prepared to ascertain the recovery obtained in the evaporation/fire assay and the reaction with Amborane resin. In each of these experiments, 4-1iter batches of synthetic brine prepared from U1trex or reagent-grade $\mathrm{NaCl}$ and $\mathrm{KCl}$ were spiked with the appropriate quantities of the $\mathrm{Pt}, \mathrm{Au}$, and $\mathrm{Ag}$ solutions. 


\section{Chemical Analysis Procedures}

The precious metals $\mathrm{Pt}, \mathrm{Au}$, and $\mathrm{Ag}$ were each determined by several methods. One technique involved a fire assay (Beamish and Van Loon, 1977) of the evaporated salts from the high-salinity brines. In this technique, for highest sensitivity, $\mathrm{Pt}$ and $\mathrm{Ag}$ were collected in $\mathrm{Au}$ and measured, respectively, by emission spectrography and atomic absorption spectrophotometry. Gold was determined by collection in Ag followed by atomic absorption spectrophotometry. The Amborane resin beads were also subjected to a fire assay for $\mathrm{Pt}, \mathrm{Au}$, and $\mathrm{Ag}$ after roasting in air. The fire assay determinations were performed by Ledoux and Company of Teaneck, New Jersey.

The samples were also surveyed for strategic metals by neutron activation analysis (Guinn, 1971). General Activation Analysis of San Diego assayed all of the liquid samples for $\mathrm{Au}$ and $\mathrm{Pt}$ using the following procedure. The samples plus comparator standards were irradiated for 30 min. in a TRIGA Mark I nuclear reactor at a flux of $1.8 \times 10^{12}$ $\mathrm{n} / \mathrm{cm}^{2}-\mathrm{sec}$. After a decay of 3 days they were wet-ashed in the presence of Au carrier. Gold was then separated as the element and counted with a $\mathrm{Ge}(\mathrm{Li})$ detector coupled to a multichannel gamma-ray spectrometer. The Au-198 and Au-199 isotopes thus measured in the irradiated sample corresponded to the $\mathrm{Au}$ and $\mathrm{Pt}$, respectively, in the original water sample. Silver in the Elmore No. 2 brine was determined by directly counting a sample of the original, irradiated brine after a delay of 3 months.

Manganese, Sr, Co, V, and Li were determined by inductively-coupledplasma emission spectrometry (Peck, et al, 1979). Tin, $\mathrm{Cr}, \mathrm{Nb}$, and Ta were determined using a Spectrametrics, Inc. DC-PIasma Spectrospan system. 
RESULTS AND DISCUSSION

Non-Precious Metals Analyses

Table 2 summarizes the results of the analyses of the collected waters for all of the elements of interest except the precious metals, $\mathrm{Au}, \mathrm{Ag}$ and Pt. For all of the fluids, the concentrations of $\mathrm{Co}, \mathrm{Sn}, \mathrm{Cr}$, and $V$ were very low or undetected at the parts-per-million level. No Nb or Ta was found either, but the detection limits for these elements were relatively higher, especially for the high-salinity brines where spectral interferences and other matrix effects make these determinations less sensitive. Separation of the Nb or Ta prior to measurement appears to be required for a more accurate analysis at the leveis that may exist. The Strategic Petroleum Reserve brines are generally devoid of interesting concentrations of all of the metals sought, including the precious metals.

As has been evident from previous studies and compilations of data (Austin, et al, 1977; Cosner and Apps, 1978; Maimoni, 1982; Shannon, 1978), the higher salinity geothermal and geopressured-geothermal (Karkalits and Hankins, 1981; Kharaka, et al, 1979) brines do contain significant concentrations of $L i$ and $S r$. Lithium has been the subject of efforts in mineral recovery at the Cerro Prieto, Mexico, facility where its fluid concentrations are also high (Mercado, et a1, 1979). A survey of the results of the analyses of the fluids of a number of wells in the Salton Sea KGRA (Austin, et al, 1977; Cosner and Apps, 1978; Shannon, 1978) shows that the concentration of $\mathrm{Sr}$ is in the range of $300-500 \mathrm{ppm}$. Interestingly, the somewhat lower-salinity geopressured-geothermal brines contain twice as much Sr (Karkalits and Hankins, 1981; Kharaka et al, 1979), and might be useful sources of this element. The high concentrations of $M n$ in the Salton Sea KGRA brines, in the range of 1000 ppm (Austin, et a1, 1977; Cosner and Apps, 1978; Shannon, 1978), 
have stimulated several recent mineral recovery studies (Crane, 1982; Farley et al, 1981; Maimoni, 1982; Schultze and Bauer, 1982).

\section{Precious Metals Analyses}

Table 3 summarizes the results of fire assay analyses performed on the solids obtained by evaporation of the various high-salinity brines. This method was chosen because the high-salinity brines could easily be concentrated by a factor of 4-5 in this manner, and fire assay is widely regarded as the most reliable technique for the analysis of solids such as ores for the precious metals.

As noted in Table 3, three types of blanks were subjected to analysis. Une was a $20 \%$ solution of $\mathrm{ACS}$ reagent-grade $\mathrm{NaCl}$; one was a solution that was $15 \%$ in $\mathrm{NaCl}$ and $4 \%$ in $\mathrm{KCl}$, both of which were Ultrex-grade salts, and one was a sample of Pacific Ocean water obtained several miles off the California coast. None of these samples were expected to contain measurable levels of $\mathrm{Ag}, \mathrm{Au}$, or Pt. The reported results for these elements indicate apparent background levels of 21.4 , 20.4, and $20.1 \mathrm{ppm}$, respectively, for $\mathrm{Ag}, \mathrm{Au}$, and $\mathrm{Pt}$ in the evaporated solids. For a 20 wt.\% brine, these values are equivalent to concentrations of, respectively, 0.3,0.08, and $0.02 \mathrm{ppm}$ in the liquid. Almost all of the brine samples yielded results for silver, gold, and platinum that were indistinguishable from those for the true blanks. We thus used these values to calculate a more accurate value for the mean and standard deviation of the blanks, and from these, limits of detection of the evaporation/fire-assay method. Listed in Table 3 are the mean values of the blanks and limits of detection (LOD) calculated from $L O D=$ $\bar{b}+3 s$, where $\bar{b}$ is the mean value of the blank and $s$ is its standard deviation (American Chemical Society Committee, 1980; Koch, et al 1982). 
All of the results of the brine analyses were then corrected for the mean values of the blanks determined in this manner.

As shown in Table 3 , the experiment with the standard revealed that concentrations of $\mathrm{Ag}, \mathrm{Au}$, and $\mathrm{Pt}$ 2-3 times the background levels were easily detected. This standard, in addition to the spiked amounts of Ag, $\mathrm{Au}$, and $\mathrm{Pt}$, contained $14 \% \mathrm{Ultrex} \mathrm{NaCl}$ and $3 \% \mathrm{Ultrex} \mathrm{KCl}$ to simulate a high-salinity brine. Recovery values for the standard are $2100 \%$, 2100\%, and 250\%, respectively for $\mathrm{Ag}, \mathrm{Au}$, and Pt. However, these values must be regarded with some uncertainty because only one standard was analyzed. Among the fire assays of these brines, only the result for Pt in Elmore No. 2 is significantly higher than the limit of detection.

As the primary assay of the low-salinity geothermal fluids, and as a second, independent analysis of the high-salinity brines, the samples were also analyzed directly by neutron activation analysis. As described above, this technique is a highiy-selective carrier precipitation that separates the $\mathrm{Au}$ and $\mathrm{Pt}$ from the other constituents prior to measurement. It is extremely sensitive for $A u$, and only high concentrations of Au would interfere with the Pt determination.

The concentrations of $\mathrm{Au}$ and $\mathrm{Pt}$ in the fluids that were calculated from the results obtained by neutron activation analysis are listed in Table 4. As in the fire assay, about one-half of these analyses were performed on diluted brine, and the values listed in Table 4 have been corrected for this dilution. The effective mean blank and limit-ofdetection values were also calculated for these data as described for the fire assays, and these results are also listed in Table 4. For most of these analyses, the concentrations of $\mathrm{Au}$ and Pt were less than the inherent detection limits of the radioactivity counting technique. 
Correcting the two positive results for the mean blank values yields values for $0.06 \mathrm{ppb}$ Au for the Raft River No. 1 water and $51 \mathrm{ppb} \mathrm{Pt}$ for the Elmore No. 2 brine: The latter result thus tends to confirm the fire assay value for Pt in this brine. The lower value for Pt obtained by evaporation/fire assay, $12 \mathrm{ppb}$, could have come from losses in the extensive sample processing involved in this procedure; analysis of the standard for $\mathrm{Pt}$ also did not yield a quantitative recovery.

Silver was not initially determined by the neutron activation technique because accurate results would have required an additional separation. However, after a delay of 3 months to allow the radioactivity to decay, when a more favorable signal could be obtained, the Elmore, No. 2 sample was counted and estimated to contain (in the original brine) $45 \pm 23 \mathrm{ppb} \mathrm{Ag}$. This value, although accompanied by a fairly large uncertainty, is lower by a factor of 10 than most values previously reported for Salton Sea KGRA brines (Austin, et al, 1977; Cosner and Apps, 1978; Shannon, 1978). This result is in agreement with a study conducted at SRI International (Farley et al, 1981), which showed that many previous analyses of such brines by direct AAS without background correction may be in error due to matrix interferences. These investigators found a value of $20 \mathrm{ppb}$ for Magmamax No. 1 brine after dithizone/solvent extraction. Thus, although $\mathrm{Ag}$ is indisputably an important constituent of the high-temperature scales (Austin, et al, 1977) and sludges (Featherstone and Powell, 1981) formed by the Salton Sea KGRA brines, its concentration in the fluid itself may not be as high as previously believed.

In the present study, each of the low-salinity waters (EMb-2, C7bB7, HGP-A, RRI, RR3, and WI) were analyzed by direct AAS, but no silver was found above the limit of detection of $20 \mathrm{ppb}$. 
Amborane Resin Extractions

Experiments were performed to determine whether the precious metals could be extracted from the brines using a resin, Amborane-355, which is specific for elements low in the electromotive series, i.e., those that are relatively easy to reduce to the metals. The resin is a polymeric amine-borane resin, and is a relatively mild reducing agent, thus is quite selective for gold, silver, and the platinum metals (Rohm and Haas, 1980; Manziek, 1982). Our experiments had a twofold objective. First, if the resin proved effective in the case of our brines, the extraction would afford a preconcentration for the fire assay and thus a much greater sensitivity in the overall analysis. In addition, if the extraction recovery proved high, the resin might be considered promising in larger-scale mineral recovery processes.

The results of the reductive-resin metal recovery experiments are given in Table 5 for the various fluids that were sampled. A portion of the as-received resin was also submitted as a blank for the fire-assay analysis. Because the weight of resin used was $230 \mathrm{~g}$, and the quantity of original fluid contacted was $2-4 \mathrm{~kg}$, a potential preconcentration factor of 2100 was operative.

The effective mean blank values and limits of detection were also calculated for this method as described above and these values are also listed in Table 5. The only result for a water that exceeds the LOU is that for gold in Coso Hot Springs 7587. correcting for the blank yields a concentration of $27 \mathrm{ppb}$; however, this result was not confirmed by the neutron activation analysis of this water (see Table 4). Note that although the other two methods detected platinum in the Elmore No. 2 brine, none was recovered in this resin recovery experiment. The large preconcentration factor yields a fairly good overall sensitivity for $\mathrm{Pt}$ 
and $\mathrm{Au}$, but not for $\mathrm{Ag}$, where there is a relatively high background of 5-6 ppm for the resin itself.

A series of experiments was also conducted using synthetic brines spiked with the precious metals to determine effect of $\mathrm{pH}$, salinity, and equilibration time on the recovery of the metals. Of particular concern to us was the recent report by Manziek (1982) on the recovery of platinum from chloride solutions. He found that recoveries of platinum at the 1000-ppm level were good for short contact times; but on prolonged standing of the resin with the solution, the platinum was reoxidized and leached from the resin, especially when gold was also present. In our experiments we used a much higher concentration of chloride, and much lower concentrations of the precious metals- $-20.5 \mathrm{ppm} \mathrm{Ag}, 20.09 \mathrm{ppm}$ $\mathrm{Au}$, and $20.05 \mathrm{ppb} \mathrm{Pt}$ in the solution. The results are summarized in Table 6.

There was reasonably good recovery under all conditions for $\mathrm{Ag}$ and $\mathrm{Au}$, and excellent recovery for Pt. There were no replicates, thus the statistical uncertainties are unknown, but it appears that the metal recoveries are not particularly sensitive to $\mathrm{pH}$ or chloride concentration. Because it was thought initially that the resin/brine equilibration time might have had an effect on the recovery of $\mathrm{Pt}$, another experiment was done with aged Elmore No. 2 brine in which the resin was allowed to contact the brine for only 1 hour before filtration. However, the concentration of $\mathrm{Pt}$ reported for the resin from this experiment was not significantly above that of the blank.

There still remains the question of whether the Amborane resin can extract trace amounts of the precious metals, particularly Pt, from the real brines. As Manziek (1982) has shown, Pt is sensitive to reoxidation, and our simulated brines lacked one constituentof real 
brines, iron, which might be capable of effecting this reaction. The Elmore No. 2 geothermal brine contains $2570 \mathrm{ppm}$ iron, which is initially present largeily as $\mathrm{Fe}^{2+}$ in the anoxic fluia. This ferrous iron would not be a factor in the reoxidation; however, on sampling and storing the brine under normal conditions, the brine becomes aerated, $\mathrm{Fe}^{2+}$ is oxidized to $\mathrm{Fe}^{3+}$, and then $\mathrm{Fe}^{3+}$ might be capable of reoxidizing constituents in the resin. In any event, further experiments would be required to confirm such a reaction, and if important, steps could be taken in mineral recovery processes to avoid allowing aeration of the fluid in the flow system.

\section{COMPARISON OF ANALYTICAL METHODS}

It is of interest to compare in more detail the sensitivities of the three analytical methods that were used to measure the concentration of precious metals in the water samples. Table. 7 summarizes, for each of the techniques, and each of the precious metals, the mean blank, its standard deviation, and a limit of detection (LOU), calculated as described above. Also listed is the calculated limit of quantitation (LOQ), which is defined as a level above the blank ten times the standard deviation of the blank (ACS Committee, 1980; Koch, et al, 1982).

For the fire assays of the evaporated solids, the $L O D$ and $L O Q$ values were calculated for a typical high-salinity brine, in which evaporation would result in a concentration factor of 25 . For the extraction with Amborane resin, a preconcentration factor of 100 was assumed. The neutron activation analysis technique is assumed to be applied directly to the original water samples, some of which were diluted in our study. Neutron activation analysis is clearly the most sensitive technique for the determination of gold (and for silver, as well, based on the one 
measurement of Elmore No. 2 brine.). The levels of the blanks are too high for the fire assays of either the solids or the resins to be useful for the measurement of silver. Atomic absorption spectrophotometry without preconcentration by solvent extraction is also probably inadequate for silver, if the allowable variability of the blank is considered.

For platinum, the large preconcentration factor afforded by the resin extraction, together with the high sensitivity of the fire assay with spectrographic finish, make this technique, in theory, the most sensitive. A limit of detection of $22 \mathrm{ppb}$ appears possible, and was virtually achieved in the recovery studies with synthetic brines (see Table 6). This fact, however, begs the question of why the platinum detected in the Elmore No. 2 brine by the other two techniques was not removed by the resin extraction. Be that as it may, neutron activation analysis with carrier precipitation emerges as more attractive in the present application because of its greater simplicity and adequate sensitivity. Of course, there is a wealth of other trace analysis techniques in the literature that may also be suitable for determining these precious metals, and as mineral recovery receives increasing emphasis, these alternatives should be investigated.

\section{CONCLUSIONS}

The principal finding of this investigation is the presence of $\mathrm{Pt}$ at a concentration of $a 50 \mathrm{ppb}$ in a Salton Sea KGRA geothermal brine from the well Elmore No. 2. This is most probably related to hydrothermal alterations of the surrounding country rocks, although it is speculated that these brines are a combination of magmatic and meteoric origin. Platinum was detected by two different analytical techniques: fire assay 
of the evaporated salts and carrier precipitation/neutron activation analysis. However, attempts to extract the platinum (and other precious metals) from this and other geothermal and SPR brines using a reductive resin yielded negative results, even though simulated $\mathrm{NaCl}$ brines were shown to be amenable to this approach. Further laboratory and field studies should be performed to determine the effects of some of the minor constituents in such brines on the recovery of precious metals by this technique. Other techniques such as electrolytic extraction and the use of activated carbon should also be investigated. If possible, other samples of geothermal fluids should be obtained from other wells at the Salton Sea KGRA to confirm and assess the extent of Pt in this resource. Among the other strategic metals of primary interest: $\mathrm{Cr}, \mathrm{Co}, \mathrm{Sn}$, and Ta could not be detected in any of the fluids. Chromium and Co concentrations are below $0.5 \mathrm{ppm}$, and $\mathrm{Sn}$ is below $1 \mathrm{ppm}$. The analytical sensitivity for Ta was poor for the technique used, 1-12 ppm. As was known from previous studies, the concentration of $\mathrm{Mn}$ in the Salton Sea KGRA brine is very high, $21000 \mathrm{ppm}$ or more, and at the present time this element is of considerable interest from the point of view of . mineral recovery. A determination of $\mathrm{Ag}$ that yielded a value of $45 \pm 23$ ppb for the Elmore No. 2 brine lends support to the contention that the higher values previously found for many Salton Sea KGRA brines are in error.

For the high-salinity brines, in which significant concentrations of precious metals are more likely to be found, the limit of detection of the fire assay as applied to the evaporated solids is not low enough for accurate determinations of the precious metals. Limits of detection ( $3 \sigma$ ) of $0.5 \mathrm{ppm} \mathrm{Ag}, 0.14 \mathrm{ppm} \mathrm{Au}$, and $0.026 \mathrm{ppm} \mathrm{Pt}$ were established for this technique. Atomic absorption spectrophotometry with preconcentration by solvent extraction appears to be a better technique for $\mathrm{Ag}$. Neutron 
activation analysis with carrier precipitation is the best technique for $\mathrm{Au}$ and $P t$, except when the ratio of $A u: P t$ is excessive. This technique will yield limits of detection of $20.04 \mathrm{ppb} \mathrm{Au}$ and $27 \mathrm{ppb} \mathrm{Pt}$ in the original fluid. For Pt, extraction with Amborane resin and fire assay of the dried resin is capable of a limit of detection of $2 \mathrm{ppb}$, but it has yet to be demonstrated with a real brine.

\section{ACKNOWLEDGEMENTS}

The spectroscopic analyses performed at LLNL were done by $R$. Lim and A. L. Langhorst, Jr. The authors are grateful to a number of individuals for permission to sample the various well fluids, and to the many well-site operating personnel and scientists whose courtesy and assistance facilitated the sampling. This work was supported by the Division of Advanced Energy Projects, Office of Basic Energy Sciences, Department of Energy, and was performed by the Lawrence Livermore National Laboratory

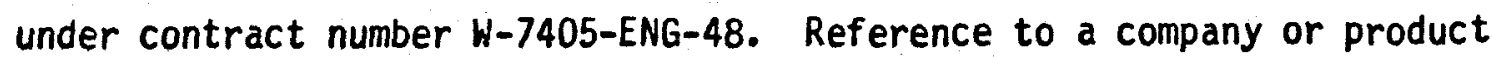
name does not imply approval or recommendation of the product by the University of California or the Department of Energy to the exclusion of others that may be suitable.

\section{DISCLAIMER}

This document was prepared as an account of work sponsored by an agency of the I nited States (iovernment. Neither the Lnited States Government nor the I niversity of California nor any of their employees, makes any warranty, express or implied. or assumes any legal liability or responsibility for the accuracy, completeness, or usefulness of any information, apparatus, product, or process disclosed, or represents that its use would not infringe privately owned rights. Reference herein to any specific commercial products. process, or service by trade name, trademark, manufacturer, or otherwise. does not necessarily constiture or imply its endorsement, recommendation, or favoring by the linited States Government or the Cniversity of California. The views and opinions of authors expressed herein do not necessarily state of reflect those of the Linited States Govemment thereof, and shall not be used for advertising or product endorsement purposes. 


\section{REFERENCES}

ACS Committee on Envirönmental Improvement, 1980. Guidelines for Data Acquisition and Data Quality Evaluation in Environmental Chemistry. Anal. Chem., 52: 2242-2249.

Austin, A.L., Lundberg, A.W., Owen, L.B., and Tardiff, G.E., 1977. The LLL Geothermal Energy Program Status Report, January 1976-January 1977. Lawrence Livermore National Laboratory Rept. UCRL-50046-76, pp. $87-89$.

Beamish, F.E. and Van Loon, J.C., 1977. Analysis of Noble Metals. Academic Pres,, New York, N.Y., chapters 6 and 7.

Cosner, S.R. and Apps, J.A., 1978. A Compilation of Data on Fluids from Geothermal Resources in the United States. Lawrence Berkeley Laboratory Kept. LBL-5936.

Crane, C.H., 1982. Experience with Minerals Recovery from Geothermal and Other Brines. Geotherm. Res. Council Trans., 6: 437-440.

Davis, R.M., 1981. National Strategic Petroleum Reserve. Science, 213: 618-622.

Farley, E.P., Watson, E.L., MacDonald, D.D., Bartlett, R.W., and Krishnan, P., 1981. Recovery of Heavy Metals from High Salinity Brines. U.S. Bureau of Mines Rept. OFR-91-81.

Featherstone, J.L. and Powell, D.R., 1981. Stabilization of High-Saline Geothermal Brines. J. Pet. Tech., 21: 727-734. Guinn, V.P., 1971. Activation Analysis. In: I.M. Kolthoff and P.J. Elving (Editors), Treatise on Analytical Chemistry, Wiley-Interscience, New York, N.Y., Part I, vol. 9, chapter 98. 
Karkalits, O.C. and Hankins, B.E., 1981. Chemical Analysis of Gas and

Brine from MGT-DUE Sweet Lake Design Well. Proc. 5th Cong. Geopressured-Goethermal Energy. Baton Rouge, pp. 331-334.

Kharaka, Y.K., Lico, M.S., Wright, V.A., and Carothers, W.W., 1979.

Geochemistry of Formation Waters from Pleasant Bayou No. 2 Well and

Adjacent Area in Coastal Texas. Proc. 4th U.S. Gulf Coast

Geopressured-Geothermal Energy Conf. Austin, Texas, vol. 1, p. 171. Koch, 0.G., LaFleur, P.D., Morrison, G.H., Jackwerth, E., Townshend, A., and Tolg, G., 1982. Comparison of the Abilities of Trace Analytical Methods to Determine Small Amounts or Concentrations of Elements, Pure \& Appl. Chem., 54: 1565-1577.

Laxen, D.P.H. and Harrison, R.M., 1981. Cleaning Methods for Polythene Containers Prior to the Determination of Trace Metals in Freshwater Samples. Anal. Chem. 53: 345-350.

Maimoni, A. and Borg, I.Y., 1981. Strategic Materials Shortages:

Institutional and Technical Issues. Lawrence Livermore National Laboratory Rept. UCRL-53203.

Maimoni, A., 1982. A Cementation Process for Mineral Recovery from

Salton Sea Geothermal Brines. Lawrence Livermore National Laboratory Rept. UCKL-53252; and references therein.

Maimoni, A. and Borg, I.Y., 1982. How Vulnerable are U.S. Resources of

Strategic Materials? Lawrence Livermore National Laboratory Energy \&

Techno1. Rev., UCRL-52000-82-2: pp. 1-10.

Manziek, L., 1982. Amborane Resins: A New Approach to the Recovery of

Precious Metals. Paper presented at 6th Int1. Precious Metals Conf., Newport Beach, CA, June, 1982. 
Mercado, S., Lopez, J.A., and Angulo, R., 1979. Chemical Recovery as

Alternative of Environmental Solution by Geothermal Brines of Cerro

Prieto (sic). Geothermal Res. Council Trans., 3: 449-452.

Peck, E.S., Langhorst, A.L., and O'Brien, D.W., 1979. Analysis of

Natural Waters with an Automated Inductively-Coupled Plasma

Spectrometer System. Lawrence Livermore National Laboratory Rept. UCRL-81043.

Raber, E., Harrar, J., and Gregg, D., 1981. An Approach to Recover

Strategic Metals from Brines. Lawrence Livermore National Laboratory Rept. UCID-19208.

Robertson, D.E., 1968. The Adsorption of Trace Elements in Sea Water on Various Container Surfaces. Anal. Chim. Acta, 42: 533-536.

Robertson, D.E., 1972. Contamination Problems in Trace Element Analysis and UItrapurification. In: M. Zief and K. Speight (Editors)

Ultrapurity, Methods and Techniques, Marcel Dekker, New York, N.Y., chapter 12.

Rohm and Haas Co., 1980. Amborane 355 Reductive Resin. Data Sheet DIC-79-3.

Schultze, L.E., and Baver, D.J., 1982. Comparison of Methods for

Recovering Metal Values from Salton Sea KGRA Brines. Geotherm. Res. Council Trans., 6: 111-113.

Shannon, D.W., 1978. Brine Chemistry and Combined Heat/Mass Transfer.

Electric Power Research Institute Rept. EPRI ER-635, vol. 2. Wei, M.S., 1982. Potential for Recovery of By-Products from Spent

Geothermal Fluids. Geotherm. Res. Council Trans., 6: 483-486. Westhusing, K., 1981. Department of Energy Geopressured Geothermal Program, Proc. 5th Conf. Geopressured-Geothermal Energy. Baton Rouge, pp. 3-6. 
TABLE 1. Waters sampled for strategic metals

\begin{tabular}{|c|c|c|c|c|}
\hline Well & Developer/Owner & Location/KGRA ${ }^{2}$ & $\begin{array}{c}\text { Water } \\
\text { Designation }\end{array}$ & $\begin{array}{c}\text { Approximate } \\
\text { Total Dissolved } \\
\text { Solids, wt. } \% \\
\end{array}$ \\
\hline \multicolumn{5}{|c|}{ Strategic Petroleum Reserve } \\
\hline $\begin{array}{l}106 A \\
110 C \\
101 \\
8 A \& B^{C} \\
7 C \\
62\end{array}$ & $\begin{array}{l}\text { U.S.D.U.E.D } \\
\text { U.S.U.O.E. } \\
\text { U.S.U.U.E. } \\
\text { U.S.D.U.E. } \\
\text { U.S.U.O.E. } \\
\text { U.S.U.U.E. }\end{array}$ & $\begin{array}{l}\text { Bryan Mound, TX } \\
\text { Bryan Mound, TX } \\
\text { West Hackberry, LA } \\
\text { West Hackberry, LA } \\
\text { Sulphur Mines, LA } \\
\text { Sulphur Mines, LA }\end{array}$ & $\begin{array}{l}\text { BM106A } \\
\text { BM110C } \\
\text { WHI01 } \\
\text { WH8A8B } \\
\text { SM7C } \\
\text { SM6Z }\end{array}$ & $\begin{array}{l}26 \\
26 \\
25 \\
20 \\
26 \\
27\end{array}$ \\
\hline \multicolumn{5}{|c|}{ Geopressured-Geothermal } \\
\hline co Fee No. 1 & $\begin{array}{c}\text { Magma, Gulf-Technadril } \\
\text { U.S.D.O.E. }\end{array}$ & Sweet Lake, LA & SLI & 15 \\
\hline \multicolumn{5}{|c|}{ Geothermal } \\
\hline Imore No. 2 & Magma Power Co. & Salton Sea, CA & E2 & 21 \\
\hline No. $6-2$ & U.S.D.0.E. & East Mesa, CA & EM6-2 & 0.5 \\
\hline $75 B 7$ & $\begin{array}{c}\text { Cal Energy Inc./ } \\
\text { U.S. Navy }\end{array}$ & Coso Hot Springs, CA & C75B7 & 1 \\
\hline$-A$ & $\begin{array}{c}\text { Hawaiian Electric Co.l } \\
\text { U.S.D.O.E. }\end{array}$ & Puna, HI & HGP-A. & 1 \\
\hline & U.S.D.O.E. & Raft River, ID & RR 1 & 0.16 \\
\hline & U.S.D.O.E. & Raft River, ID & $\mathrm{RR} 3$ & 0.4 \\
\hline Sen No. 1 & Geoproducts Co. & Wendel-Amedee, CA & W1 & 0.13 \\
\hline
\end{tabular}

Known Geothermal Resource Area

United States Department of Energy

Composite sample 
TABLE 2. Results of chemical analyses of waters for non-precious metals by spectroscopic methods

\section{Metal Concentration, $\mathrm{mg} / \mathrm{kg}$ (ppm by wt.)}

Nater $^{a} \quad \underline{L i} \quad \underline{S r} \quad \underline{C_{0}} \quad \underline{M n} \quad \underline{S_{n}} \quad \underline{C_{r}} \quad \underline{v} \quad \underline{N b} \quad \underline{T a}$

Strategic Petroleum Reserve

$\begin{array}{llllllllll}\text { BMI06A } & 0.25 & 2.0 & <0.37 & <0.03 & <0.8 & <0.2 & <0.15 & <3 & <12 \\ \text { BM110C } & 0.21 & 2.2 & <0.40 & <0.03 & <0.8 & <0.2 & <0.16 & <3 & <12 \\ \text { WH101 } & <0.12 & 2.1 & <0.30 & <0.02 & <0.7 & <0.2 & <0.12 & <3 & <12 \\ \text { WH8A8B } & <0.11 & 2.4 & <0.30 & <0.02 & <0.3 & <0.2 & <0.11 & <3 & <5 \\ \text { SM7C } & <0.18 & 1.4 & <0.44 & <0.04 & <0.4 & <0.2 & <0.18 & <4 & <3 \\ \text { SM62 } & <0.16 & 1.2 & <0.40 & <0.03 & <0.4 & <0.1 & <0.16 & <4 & <4\end{array}$

Geopressured-Geothermal

SLI $\quad 36 \quad 860 \quad<0.50 \quad 15 \quad<2 \quad<0.1 \quad 0.3 \quad<10<10$

Geothermal

\begin{tabular}{llllllllll} 
E2 & 132 & 301 & 0.43 & 995 & $<2$ & $<0.2$ & 1.1 & $<6$ & $<15$ \\
EM6-2 & 4.3 & 2.0 & $<0.005$ & 0.005 & $<0.1$ & $<0.1$ & $<0.002$ & $<0.1$ & $<1$ \\
C75B7 & 25 & 3.7 & 0.008 & 0.007 & $<0.2$ & $<0.2$ & 0.010 & $<0.2$ & $<2$ \\
HGP-A & 0.034 & 2.0 & 0.014 & 0.034 & $<0.2$ & $<0.2$ & 0.016 & $<0.4$ & $<2$ \\
RR1 & 1.5 & 1.3 & $<0.005$ & 0.003 & $<0.1$ & $<0.1$ & $<0.002$ & $<0.1$ & $<1$ \\
RR3 & 2.5 & 3.9 & $<0.005$ & 0.025 & $<0.1$ & $<0.1$ & 0.007 & $<0.3$ & $<1$ \\
W1 & 0.23 & 0.74 & $<0.005$ & 0.002 & $<0.1$ & $<0.1$ & $<0.003$ & $<0.1$ & $<1$ \\
\hline
\end{tabular}

àsee Table 1 for sample code. 
TABLE 3. Results of fire assays of solids from evaporation of brines

\begin{tabular}{|c|c|c|c|c|c|c|c|}
\hline \multirow[b]{2}{*}{ water } & \multirow[b]{2}{*}{ Sample Type } & \multicolumn{3}{|c|}{$\begin{array}{l}\text { Reported } \\
\text { Conc. in Solids, mg/kg } \\
\end{array}$} & \multicolumn{3}{|c|}{$\begin{array}{l}\text { Calculated } \\
\text { Conc. in Brine, } \mathrm{mg} / \mathrm{kg}\end{array}$} \\
\hline & & $\underline{\mathrm{Ag}}$ & $\underline{A u}$ & $\underline{\mathrm{Pt}}$ & $\mathrm{Ag}$ & $\underline{\text { Au }}$ & $\underline{\mathrm{Pt}}$ \\
\hline \multicolumn{8}{|c|}{ Test Samples } \\
\hline SBI & Blank, ACS Reag. NaCl & 1.4 & 0.31 & 0.10 & -- & -- & -- \\
\hline SB2 & Blank, Ultrex $\mathrm{NaCl}, \mathrm{KCl}$ & 1.4 & 0.31 & 0.10 & -- & -- & -- \\
\hline$S A$ & Blank, Ocean Water & 0.9 & 0.31 & 0.10 & -- & -- & -- \\
\hline SS1 & Standard & 4.3 & 1.07 & 0.28 & 0.55 & 0.113 & 0.033 \\
\hline & Prepared to Contain: & 2.8 & 0.66 & 0.40 & 0.49 & 0.114 & 0.070 \\
\hline \multicolumn{8}{|c|}{$\underline{B r i n e ~ S a m p l e s ~}^{a}$} \\
\hline BM106A & SPR Brine & 1.6 & 0.51 & 0.07 & $<0.6$ & $<0.17$ & $<0.033$ \\
\hline BMIIOC & " & 1.2 & 0.34 & 0.10 & $<0.6$ & $<0.17$ & $<0.033$ \\
\hline WH1OI & $"$ & 1.3 & 0.41 & 0.07 & $<0.6$ & $<0.17$ & $<0.033$ \\
\hline WH8A8B & $"$ & 1.7 & 0.55 & 0.07 & $<0.6$ & $<0.17$ & $<0.033$ \\
\hline SM7C & $"$ & 1.8 & 0.45 & 0.07 & $<0.6$ & $<0.17$ & $<0.033$ \\
\hline SM6Z & $"$ & 1.3 & 0.45 & 0.07 & $<0.6$ & $<0.17$ & $<0.033$ \\
\hline SLI & Geopressured-Geothermal & -- & 0.50 & $<0.02$ & -- & $<0.10$ & $<0.020$ \\
\hline E2 & Hyarothermal-Geothermal & 1.8 & 0.35 & 0.14 & $<0.05$ & $<0.14$ & 0.012 \\
\hline \multicolumn{2}{|c|}{ Mean blank } & 1.4 & 0.41 & 0.083 & & & \\
\hline \multicolumn{2}{|c|}{ Limit of vetection $b$} & 2.3 & 0.68 & 0.13 & & & \\
\hline
\end{tabular}

asee Table 1 for sample code.

Mean blank $+3 \times$ (standard deviation of blank) 
TABLE 4. Results of neutron activation analysis of waters for gold and platinum

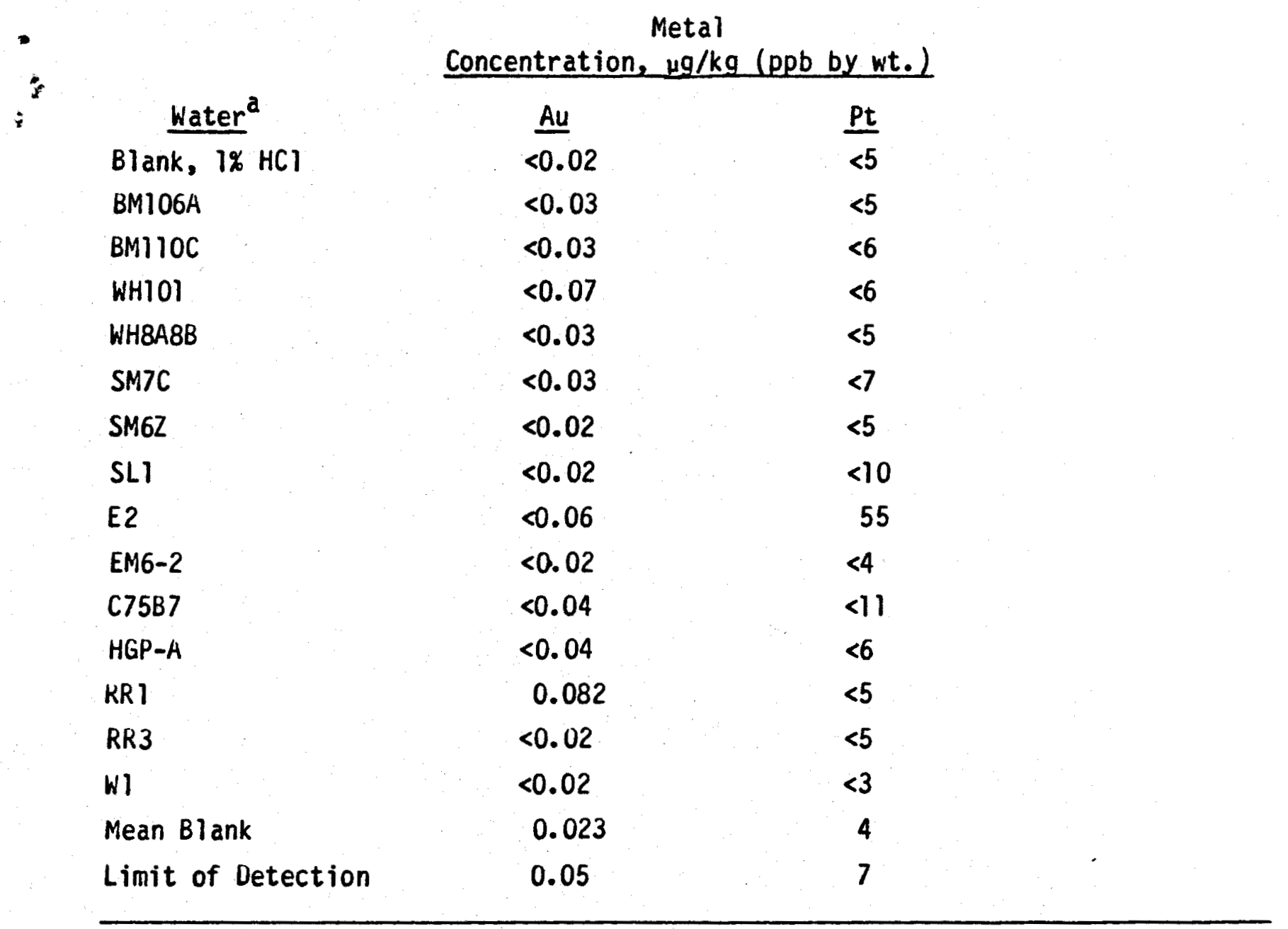

asee Table 1 for sample code 
TABLE 5. Results of fire assays of Amborane resins after contacting brines. (Original water samples undiluted and unacidifed except as noted.)

Reported Calculated

Conc. in Resin, $\mathrm{mg} / \mathrm{kg}$ Conc. in Brine, $\mathrm{\mu g} / \mathrm{kg}$ (ppb)

$-$

\begin{tabular}{|c|c|c|}
\hline Hater & Sample Type & \\
\hline & Untreated $R$ & Resin \\
\hline BMI06A & SPR Bri & ine \\
\hline BMIIOC & $"$ & u \\
\hline WH10I & " & \\
\hline WHEA8B & " & \\
\hline SM7C & $"$ & \\
\hline$E 2^{b}$ & Geothermal & Brine \\
\hline EM6-2 $2^{C}$ & $"$ & $\mu$ \\
\hline$C 75 B 7^{d}$ & $"$ & $"$ \\
\hline$C 75 B 7^{C}$ & " & " \\
\hline$H G P-A^{b}$ & $"$ & $"$ \\
\hline$H G P-A^{C}$ & $"$ & " \\
\hline $\operatorname{RR}^{C}{ }^{C}$ & $"$ & " \\
\hline $\operatorname{RR} 3^{c}$ & $"$ & " \\
\hline 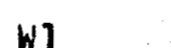 & $"$ & \\
\hline
\end{tabular}

Mean blank

Limit of Detection
$\underline{\mathrm{Ag}}$

$\underline{A u} \quad \underline{P t}$

6.8

6.0

0.99

6.0

0.99

0.07

14.9

0.99

0.10

0.07

0.99

0.14

0.99

0.10

0.99

0.07

7.5

0.99

$\underline{\mathrm{Ag}}$

Au

Pt

7.6

0.89

0.07

0.99

0.07

$<250$

-..e

2.0

0.07

2.7

$<0.03$

0.62

$<0.03$

0.62

$<0.03$

0.99

0.10

1.10

0.10

0.99

0.07

6.5

1.1

0.075

16

2.6

0.17

aSee Table 1 for sample code.

briginal sample acidified only.

Criginal sample diluted only.

- duriginal sample acidified and diluted.

- Contamination in resin analysis. 
Table 6. Results of experiments on recovery of precious metals from synthetic brines by Amborane resin

[Conc. of metals added to brine $(\mathrm{mg} / \mathrm{kg}): \mathrm{Ag} \sim 0.5$, Au 20.09 , Pt $20.05 ; 10$-day resin/brine equilibration except as noted.]

\begin{tabular}{|c|c|c|c|c|c|c|}
\hline & $\underline{\mathrm{Ag}}$ & $\underline{A u}$ & $\underline{\mathrm{Pt}}$ & & & \\
\hline Metals Added $(\mathrm{mg})$ : & 1.82 & 0.34 & 0.21 & $\underline{\mathrm{Ag}}$ & $\underline{A u}$ & $\underline{P t}$ \\
\hline Sample & \multicolumn{4}{|c|}{ Metal Kecovered, $\mathrm{mg}$} & \multirow{2}{*}{\multicolumn{2}{|c|}{$\begin{array}{l}\text { Calculated } \\
6 \text { Recovery }\end{array}$}} \\
\hline $10 \% \mathrm{NaCl}, \mathrm{pH} 7 \mathrm{Blank}$ & 0.14 & 0.037 & 0.013 & & & \\
\hline $10 \% \mathrm{NaCl}, 1 \% \mathrm{HCl}+$ Metals & 1.36 & 0.36 & 0.24 & 67 & 95 & 108 \\
\hline $10 \% \mathrm{NaCl}, \mathrm{pH} 7+$ Metals & 1.08 & 0.24 & 0.22 & 52 & 60 & 99 \\
\hline $0.5 \% \mathrm{NaCl}, \mathrm{pH} 7+$ Metals & 1.53 & 0.28 & 0.25 & 76 & 71 & 113 \\
\hline $10 \% \mathrm{NaCl}, 1 \% \mathrm{HCl}+$ Metals $\mathrm{s}^{\mathrm{a}}$ & 1.12 & 0.23 & 0.23 & 54 & 57 & 103 \\
\hline
\end{tabular}

$a_{1-h}$ resin/brine equilibration.

${ }^{b}$ Corrected for blank 
TABLE 7. Comparison of capabilities of analytical methods in the detection and determination of precious metals in brines [metal concentrations in $\mathrm{mg} / \mathrm{kg}(\mathrm{ppm})]$

Fire Assays of Evaporated Solids

Mean Blank, $\bar{b}$,

$\frac{\mathrm{Ag}}{1.4} \quad \frac{\mathrm{Au}}{0.41} \quad \frac{\mathrm{Pt}}{0.083}$

Standard Deviation of Blank, $s$

0.3

0.09

0.016

$\angle O D^{\alpha}$ in $20 \%$ brine

0.5

0.14

0.026

$L O Q^{b}$ in $20 \%$ brine

0.9

0.26

0.049

Extraction, Fire Assay of Amborane Resin

\begin{tabular}{|c|c|c|c|}
\hline & $\mathrm{Ag}$ & $\mathrm{Au}$ & $\mathrm{Pt}$ \\
\hline Mean Blank, $\bar{b}$ & 6.5 & 1.1 & 0.075 \\
\hline $\begin{array}{c}\text { Standard Ueviation } \\
\text { of Blank, } S\end{array}$ & 3.2 & 0.5 & 0.03 \\
\hline LOD in water; $100 x$ preconc. & 0.16 & 0.03 & 0.002 \\
\hline LOQ in water; $100 x$ preconc. & 0.39 & 0.06 & 0.004 \\
\hline
\end{tabular}

Neutron Activation Analysis with Carrier Precipitation

(Undiluted samples)

Mean Blank, $\bar{b}$

Standard Deviation

of Blank, $s$

LOD in water

LUQ in water

$a_{L O U}-$ limit of detection $=\bar{b}+3 s$

DLUQ - limit of quantitation $=\bar{b}+10 \mathrm{~s}$
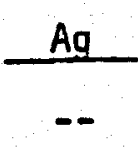

--

$-$

--
$\mathrm{Au}$

0.000023

0.000008

0.00005

0.0001
Pt

0.0041

0.0010

0.007

0.014 


\section{FIGURE CAPTION}

Figure 1. Apparatus for evaporation of brines. 


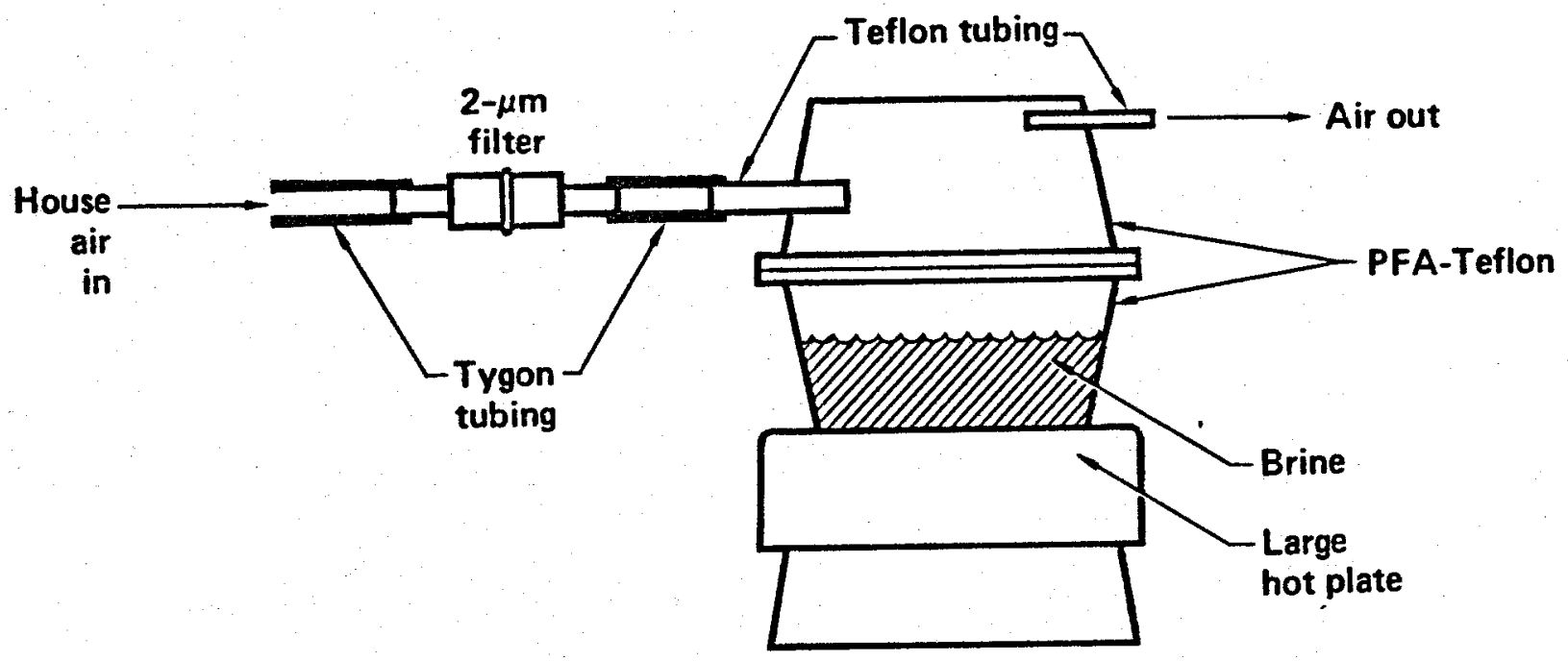

